\title{
A new case of duplication of the MDS region identified by high-density SNP arrays and a review of the literature
}

\author{
Flavio Faletra • Raffaella Devescovi • Vanna Pecile • \\ Antonella Fabretto • Marco Carrozzi • Paolo Gasparini
}

Received: 8 September 2010 /Revised: 10 October 2010 /Accepted: 11 October 2010 /Published online: 3 November 2010

(C) Institute of Plant Genetics, Polish Academy of Sciences, Poznan 2010

\section{Introduction}

The deletion of the locus $17 \mathrm{p} 13$ was associated with Miller-Dieker lissencephaly syndrome (MDLS). Deletion (Delatycki and Leventer 2009) or mutations (Lo Nigro et al. 1997) in the PAFAH1B1 (601545) gene cause lissencephaly (Gu and Lupski 2008), but facial dysmorphology and other abnormalities in patients with MDLS seem to be the result of the deletion of additional genes distal to PAFAH1B1 (Cardoso et al. 2003; Saillour et al. 2009). The gene responsible for the greater severity of MDLS compared to isolated lissencephaly is the YWHAE (Haverfield et al. 2009) (605066) gene, encoding 14-3-3-epsilon. It was very recently demonstrated that the duplication in $17 \mathrm{p} 13$ is a new clinical entity (OMIM 613215), characterized by mental retardation and other variable clinical and radiological findings (Roos et al. 2009; Spalice et al. 2009). There are three different areas within the MDS region containing dosage-sensitive genes. One containing the PAFAH1B1 gene and the other, more distal, which includes the TUSC5, YWHAE, CRK, and MYOIC genes. Until now, few cases have been described with duplication in the MDS region (Mei et al. 2008; Bi et al. 2009) and only two of them show a duplication including only the PAFAH1B1 area. All patients with duplication in the MDS region have common clinical and phenotypic features. Nevertheless, there are several important differences between those with only duplication in the PAFAH1B1 area as compared with those who have also (or only) a duplication in the distal area.

F. Faletra $(\bowtie) \cdot$ R. Devescovi $\cdot$ V. Pecile $\cdot$ A. Fabretto $\cdot$

M. Carrozzi $\cdot$ P. Gasparini

Department of Reproductive Sciences and Development, Institute of Child Health-IRCCS Burlo Garofolo,

Via dell'Istria 65 ,

34137 Trieste, Italy

e-mail: faletra@burlo.trieste.it

\section{Clinical report}

The proband, a 6-year-old girl, is the first child of nonconsanguineous parents. The family history for mental retardation or congenital disorders was negative. The proband was born at term by dystocia childbirth. At birth, the Apgar was $9 / 10$ at the first and at the fifth minute. Stages of psychomotor development were all delayed. At ten months of life, the proband had not yet acquired a sitting independent position. At 16 months, the proband started to walk, while expressing considerable difficulties. Language was still the worst affected: at about 18 months, the proband started babbling, and she was followed with a support speech therapy. To date, at the age of 6 years, the proband utters only a few isolated words. Further analysis excluded the presence of major malformations of the internal organs and of the skeletal system. The main relevant features of our case are: (A) mental retardation; (B) magnetic resonance imaging (MRI) revealed the presence of an arachnoid cyst (Fig. 2) in the posterior fossa with a consequent asymmetry of cerebellar hemispheres; (C) hypotonia, delayed psychomotor development, especially for expressive language and an autistic spectrum disorder; (D) short stature, despite the fact that the anthropometric values at birth were approximately all around the 50th percentile and a carpus radiography revealed a bone age comparable with the age of the proband; (E) phenotypic features: long face, slight synophrys, long philtrum, thin upper lip, and pointed chin (Table 1).

\section{Materials and methods}

After informed consent, the chromosomal analysis was performed on blood using the standard protocol with 440 550-band resolution. Molecular karyotyping was carried 
Table 1 Clinical features of patients with duplication or triplication in the 17p13.3 Miller-Dieker syndrome (MDS) region

\begin{tabular}{|c|c|c|c|c|c|}
\hline & Two distal genes & Four distal genes & All genes & Only the PAFAHIBI gene & \\
\hline Number of patients & 1 & 3 & 3 & 2 & Our patient \\
\hline Birth length/weight & Low & Elevated & Normal/elevated & Low & Normal \\
\hline Current length/weight & Normal & Elevated & Elevated & Low & Low \\
\hline Head circumference & Low & Elevated & Elevated/low & Low & Low \\
\hline Head & Normal & Long face/normal & Frontal bossing/normal & Triangular/microcephaly & Long face \\
\hline Eyes & Deep-set & $\begin{array}{l}\text { Mild synophrys/ } \\
\text { upslanting }\end{array}$ & Hypertelorism/downslanting & Normal & $\begin{array}{l}\text { Downslanting/mild } \\
\text { synophrys }\end{array}$ \\
\hline Nose & Broad nasal bridge & $\begin{array}{l}\text { Squared/overhanging } \\
\text { columella }\end{array}$ & Broad nasal bridge & Normal & Normal \\
\hline Mouth & Mild prognathia & $\begin{array}{l}\text { Thin upper lip/short } \\
\text { philtrum/prominent chin }\end{array}$ & Normal/small/high palate & $\begin{array}{l}\text { Micrognathia/high } \\
\text { arched palate }\end{array}$ & $\begin{array}{l}\text { Thin upper lip/long } \\
\text { philtrum/pointed chin }\end{array}$ \\
\hline Skeletal & Normal & $\begin{array}{l}\text { Large hands/scoliosis/ } \\
\text { prominent PIP joints }\end{array}$ & Normal/clinodactyly & $\begin{array}{l}\text { Craniosynostosis/ } \\
\text { dislocated hips }\end{array}$ & Normal \\
\hline $\begin{array}{l}\text { Neurological } \\
\text { abnormalities }\end{array}$ & $\begin{array}{l}\text { Reduced } \\
\text { eye contact }\end{array}$ & $\begin{array}{l}\text { Hypotonia/ADHD/ } \\
\text { suspected autism }\end{array}$ & $\begin{array}{l}\text { Hypotonia/autism/ } \\
\text { insensitivity to pain }\end{array}$ & $\begin{array}{l}\text { Hypotonia/atrophy/ } \\
\text { ADHD/OCD }\end{array}$ & $\begin{array}{l}\text { Autistic spectrum } \\
\text { disorder }\end{array}$ \\
\hline $\begin{array}{l}\text { Delayed psychomotor } \\
\text { development }\end{array}$ & $\begin{array}{l}\text { Expressive } \\
\text { language }\end{array}$ & $\begin{array}{l}\text { Mild/global/fine motor } \\
\text { delay }\end{array}$ & Mental retardation/moderate & $\begin{array}{l}\text { Mental retardation/ } \\
\text { development delay }\end{array}$ & $\begin{array}{l}\text { Mental retardation/ } \\
\text { expressive language }\end{array}$ \\
\hline $\begin{array}{l}\text { Magnetic resonance } \\
\text { imaging }\end{array}$ & N/A & $\begin{array}{l}\text { Thin corpus callosum/ } \\
\text { periventricular } \\
\text { leukomalacia }\end{array}$ & $\begin{array}{l}\text { Choroid plexus cysts/ } \\
\text { hypo/aplasia of corpus } \\
\text { callosum/mild cerebral } \\
\text { volume loss }\end{array}$ & $\begin{array}{l}\text { Subarachnoid cyst/ } \\
\text { dysgenesis of corpus } \\
\text { callosum/mild cerebral } \\
\text { volume loss/cerebellar } \\
\text { atrophy }\end{array}$ & $\begin{array}{l}\text { Arachnoid cyst/ } \\
\text { asymmetry } \\
\text { of cerebellar } \\
\text { hemispheres }\end{array}$ \\
\hline
\end{tabular}

out using single nucleotide polymorphism (SNP) array analysis using the HumanCNV370-Quad array (Illumina, San Diego, CA) according to manufacturer's protocol. This array is characterized by 370,000 SNP markers and covers specifically almost $14,000 \mathrm{CNV}$ regions. Acquired data was visualized and analyzed with GenomeStudio Data Analysis Software v.2008 (Illumina, San Diego, CA).

\section{Results}

Chromosomal analysis revealed a 46, XX karyotype. Molecular karyotype analysis by high-resolution SNP arrays performed on the proband DNA revealed a "de novo" duplication of approximately 1.2 megabases in the p13.3 region of chromosome 17 from base 1,558,949 to base 2,787,681 (Figs. 1 and 2), which encompass the PAFAH1B1 gene. No other relevant molecular alterations were detected with a possible relationship with the phenotype.

\section{Discussion}

In this report, we describe a case of mental retardation with an autistic spectrum disorder and the presence of specific alterations in the MRI results. The whole-genome study performed with SNP arrays identified a duplication in the critical MDS region. A comparison of our case with those so far described in the literature was carried out. Four cases present the duplication in the MDS region without PAFAH1B1 gene involvement. Additionally, in four cases, a large duplication involves both areas, while only two cases are duplicated within the PAFAH1B1 area. Although some craniofacial characteristics have been reported among individuals with duplication of the YWHAE gene, however, there is no pathognomonic clinical sign of facial dysmorphism or gestalt of the face described in this duplication, and these phenotypic signs may be present even if only the $P A F A H 1 B 1$ gene is duplicated. Patients primarily carrying only the duplication of the PAFAH1B1 area tend to show growth retardation and microcephaly, whereas the others manifest overgrowth. This macrosomia, as has already been reported by Bi et al. (2009), may be attributed to $C R K$, a gene involved in growth regulation and cell differentiation. Differently from that described by Bi et al. (2009), our patient, who presented a duplicate PAFAH1B1 gene, does not show any internal organ abnormality. Developmental delay, cognitive and speech difficulties, and pervasive developmental disorders were observed in all affected individuals and were the main reason for why they have been studied. The autistic spectrum disorder, present in our proband, is described in two other patients, where the duplication, however, involves different areas. Hypotonia is very frequent in this cohort of patients. MRI was not performed in all patients and, therefore, it is very difficult to perform a correlation between abnormalities detected and the duplicated genes. In any case, it is certainly interesting to note that there are some alterations in the central nervous system (CNS) that frequently recur. 
Fig. 1 Ten individuals with duplication and triplication in the MDS region identified by comparative genomic hybridization $(\mathrm{CGH})$ and single nucleotide polymorphism (SNP) arrays. The MDS region is indicated at the top of the figure. On the bottom are 11 horizontal bars showing the fine-mapping of duplications. Dark area, duplication; gray area, deletion; striped area, triplication. The asterisk for subject 7 indicates a $\sim 4-k b$ deletion

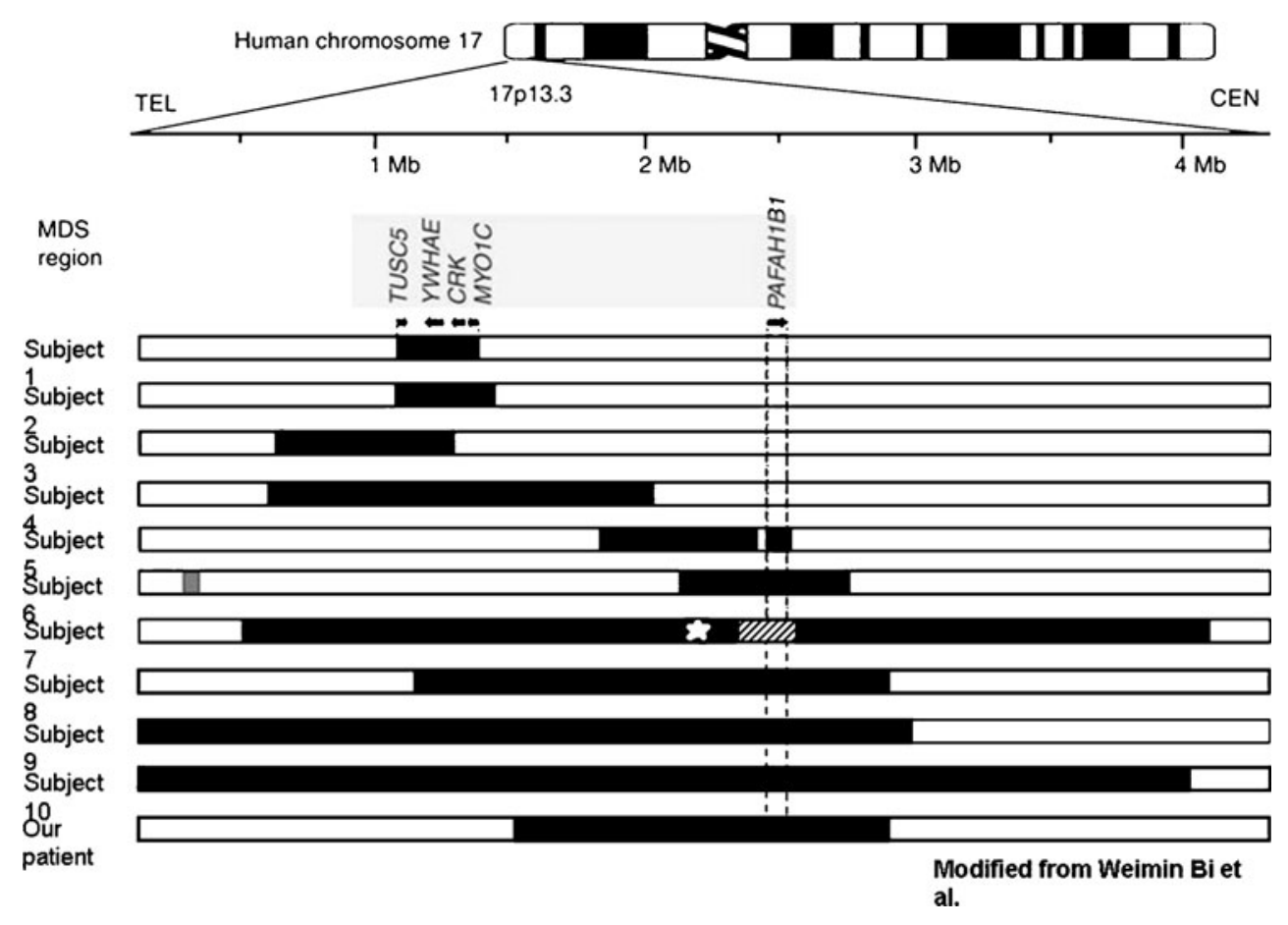

Indeed, in our case, there is the presence of cysts subarachnoid and cerebellar atrophy or asymmetry (Fig. 2), as well as in another case with only the PAFAH1B1 duplication (Bi et al. 2009). In another patient, there was also described a choroid plexus cyst. However, as already described, the MRI abnormalities are most pronounced with triplication of the PAFAHIB1 gene as compared to duplication, an observation which is consistent with a gene dosage effect.

Recently, Bruno et al. (2010) have suggested a new classification characterized by two classes of co-locating microduplications in $17 \mathrm{p} 13.3$. Class I involves $Y W H A E$ but not PAFAH1B1, and Class II involves PAFAH1B1 \pm several other genes. The clinical spectrum of our patient is in

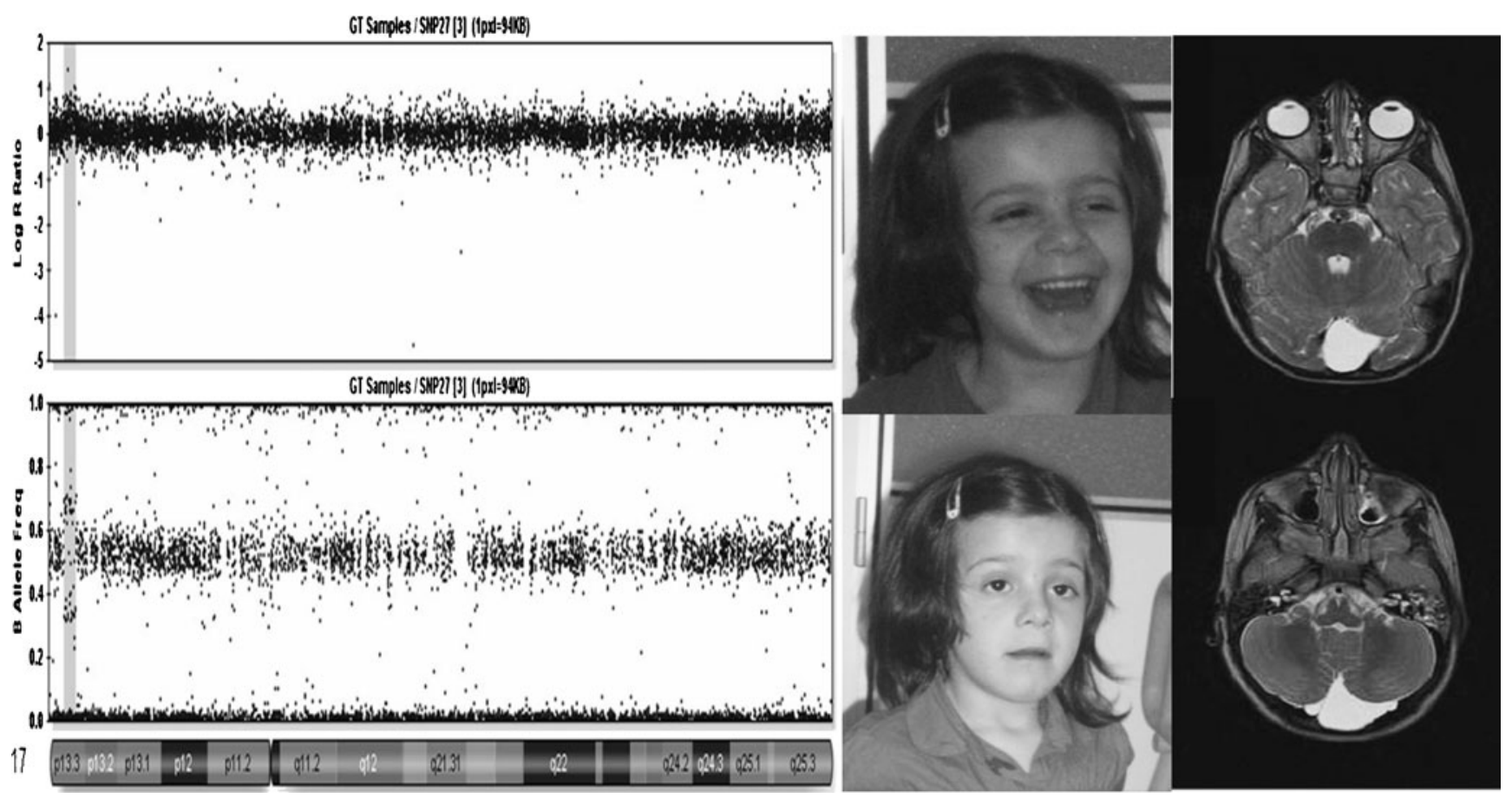

Fig. 2 a Shown is the duplication present in the 17p13.3 region. b Facial features of our patient and her magnetic resonance imaging (MRI) scans 
agreement with this new classification and overlap with those in Class II. According to Bruno et al. (2010), Class I patients show autistic manifestations, but it is important to highlight also that several patients in Class II, including our case, manifest an autistic spectrum disorder. Moreover, our patient is the only case described so far with autistic spectrum disorder and duplication involving only the PAFAH1B1 gene.

Finally, we believe that this additional case allows to better define the correlation between the phenotype, the clinical features, the radiological abnormalities, and the area of duplication in the MDS region.

\section{References}

Bi W, Sapir T, Shchelochkov OA et al (2009) Increased LIS1 expression affects human and mouse brain development. Nat Genet 41(2):168-177

Bruno DL, Anderlid BM, Lindstrand A et al (2010) Further molecular and clinical delineation of co-locating $17 \mathrm{p} 13.3$ microdeletions and microduplications that show distinctive phenotypes. J Med Genet 47(5):299-311

Cardoso C, Leventer RJ, Ward HL et al (2003) Refinement of a 400$\mathrm{kb}$ critical region allows genotypic differentiation between isolated lissencephaly, Miller-Dieker syndrome, and other phenotypes secondary to deletions of $17 \mathrm{p} 13.3$. Am J Hum Genet 72 (4):918-930

Delatycki MB, Leventer RJ (2009) Listen carefully: LIS1 and DCX MLPA in lissencephaly and subcortical band heterotopia. Eur J Hum Genet 17(6):701-702

Gu W, Lupski JR (2008) CNV and nervous system diseases-what's new? Cytogenet Genome Res 123(1-4):54-64

Haverfield EV, Whited AJ, Petras KS et al (2009) Intragenic deletions and duplications of the LISI and DCX genes: a major diseasecausing mechanism in lissencephaly and subcortical band heterotopia. Eur J Hum Genet 17(7):911-918

Lo Nigro C, Chong CS, Smith AC et al (1997) Point mutations and an intragenic deletion in LIS1, the lissencephaly causative gene in isolated lissencephaly sequence and Miller-Dieker syndrome. Hum Mol Genet 6(2):157-164

Mei D, Lewis R, Parrini E et al (2008) High frequency of genomic deletions - and a duplication - in the LISI gene in lissencephaly: implications for molecular diagnosis. J Med Genet 45(6): 355-361

Roos L, Jønch AE, Kjaergaard S et al (2009) A new microduplication syndrome encompassing the region of the Miller-Dieker (17p13 deletion) syndrome. J Med Genet 46(10):703-710

Saillour Y, Carion N, Quelin C et al (2009) LIS1-related isolated lissencephaly: spectrum of mutations and relationships with malformation severity. Arch Neurol 66(8):1007-1015

Spalice A, Parisi P, Nicita F et al (2009) Neuronal migration disorders: clinical, neuroradiologic and genetics aspects. Acta Paediatr 98 (3):421-433 